\title{
Taboo Language Expression Between SELler AND BuYER IN TRADITIONAL MARKET
}

\author{
Widya Nola Samosir ${ }^{1}$, Meisuri ${ }^{2}$, Citra Anggia Putri ${ }^{3}$ \\ ${ }^{123}$ UNIVERSITAS NEGERI MEDAN
}

\begin{abstract}
This research discussed about taboo language in Batak Toba language at Pajak Sore Padang Bulan Medan which aimed to find out the types, the impacts of taboo language expression towards customers, and how Bataknese society perceptions towards their taboo language. This research was based on Mahmoud's theory. This research was conducted by using descriptive qualitative method. The data were taken from 25 conversations of male and female participants who become sellers and customers in Traditional Market. The findings showed that there were 25 data, 20 data for the types and the impacts, 5 data for Bataknese society perceptions. The dominant types from taboo words in Batak Toba language is Insult and Slurs with 7 expressions, second is scatology with 5 expressions, followed by epithets with 3 expressions, vulgarity with 1 expression, obscenity with 1 expression. Batak sellers is the dominant use taboo language because it was their habit when they were angry but sometimes it is also a part of their close relationship, it means that how close their relationship, so they can used the taboo language. In the analyzed of the impacts of taboo language towards customers, the dominant impacts were people got offended easily and sometimes they become the people who have the irrational thinking. There were 5 perceptions of Bataknese society perceptions about their taboo language and the dominant perception were sellers and customers could not receive taboo words because they still thought that the language could have a bad impact on children because they would replicate and pronounce the taboo language.
\end{abstract}

Keywords: Taboo Words, Types of Bataknese Taboo Words, Impacts, Perceptions 


\section{INTRODUCTION}

Sociolinguistic is a part of study that focused on language which is dealing with social and cultural phenomena in one society (Yule, 2010). Language is the method of human communication, either spoken or written, consisting of the use of words in a structured and conventional way and with language we can express about something(Wardhaugh, 2006).Every person has their own way to choose the language variation which can confirm one's identity but sometimes the using of language variations depends on socio-cultural, setting, social changes, and gender.

Indonesian has one of the big islands that isNorthern Island. Northern islands has 8 ethic such as Melayu, BatakKaro, BatakSimalungun, Batak Pak-Pak/Dairi, Batak Toba, Mandailing, Pesisir, and Nias (Northen islands profile, 2020). Every ethnic has a different culture and language, that different depends on their social-culture environment, so sometimes the variations of language will be the reason that taboo language already spreading in Indonesia especially in traditional market.

Taboo or known as tabu is a Tongan term that denotes a person, object or act which is dangerous and therefore it must be avoided (Cook, 2014). The example of taboo language in Indonesian language areanjing and taik! the words means that animal and human waste that it aimed to taboo words because those words are still forbidden to be spoken in public places (Jay, 1999).

There were some assumptions that taboo language were mostly uttered by education, gender, setting, socio-cultural. In education, people believed that educational background affects the way people speak. The way people speak is an indicator of their social background. Then, people with good educational background in some occasions still use indecent and offensive language in their conversation(Mahmoud, 2013). Then, in gender men and women have differences in language use, the differences from the aspects of pronunciation, intonation, vocabulary, syntax, manners, attitudes, and non-verbal differences in using language between men and women (Yoosefi, 2017).

In setting or place, place has an important role in the using of taboo language because if someone has a relationship with good people and always speak politely, so he will speak well and vice versa. Then, socio-cultural also has the important role in the using of language because if we have a bad socio-cultural at socializing so we will talk as we like to other people, whether it is taboo language or not (Mahmoud, 2013).

In this study, the research focused on the types of taboo language in Batak Toba language, the impacts of taboo language towards customers in one of traditional market on Northern Island, and the assumption of people about taboo language.The research conducted with sociolinguistic, considering sociolinguistic is the study of language, social interaction, socio-culturalas an essential part of cultural life and communication. 


\section{RESEARCH METHODOLOGY}

This case study conducted by applied descriptive qualitative method. According to (William, 2012)Descriptive Qualitative approach for research questions need textural data. The descriptive qualitative in this study was intended to understand the types of taboo language in Bataknese, the impacts of taboo language expression, and the Bataknese society perceptions about taboo language.

The data of this study were collected byusing the observation, documentation, and interview techniques, the researcher made observation and documentation in the same time. In the observation and documentation, the researcher made observation to traditional market that is dominated by Batak people and saw what language their often say and are they always use the taboo language or not, and then the researcher recorded the conversations or video of sellers and customers who used taboo language about 5-10 minutes as the documentation. the last interviewed Batak people about their perception toward their taboo language. Next, after collected the data, the researcher classified their taboo language into the types of taboo language based on Timothy Jay's theory about 8 types of taboo language. Then, described how did the meaning of taboo language types and why can taboo language give the impacts towards customers through conversations with sellers and customers at Pajak Sore Padang Bulan Medan. Finally, explained the findings with theories in the analysis.

\section{FINDINGS and DISCUSSIONS}

\section{FINDINGS}

\section{Types of Taboo Language in Batak Toba Language}

In this research, the data can be assumed in table. The table is formulated to make the reader easy getting information about the results of the study.

Table 3.1.Data Distribution of Types of Taboo Language Between Sellers and Customers in Batak Toba Language at Pajak Sore Padang Bulan Medan.

\begin{tabular}{|r|c|c|c|c|c|c|}
\hline No. & $\begin{array}{c}\text { Types of } \\
\text { Taboo } \\
\text { Language }\end{array}$ & Gender & $\begin{array}{c}\text { Bataktoba } \\
\text { Taboo } \\
\text { language }\end{array}$ & $\begin{array}{c}\text { English } \\
\text { language }\end{array}$ & Frequency & Percent \\
\hline 1. & Cursing & Female & $\begin{array}{l}\text { Mate ma ho } \\
\text { bah! }\end{array}$ & Die! & 1 & $1 \%$ \\
\hline 2. & Profanity & Male & $\begin{array}{l}\text { Oh } \\
\text { Tuhankungaloja } \\
\text { au! }\end{array}$ & $\begin{array}{l}\text { Oh god, } \\
\text { I'm so tired! }\end{array}$ & 1 & $1 \%$ \\
\hline
\end{tabular}




\begin{tabular}{|c|c|c|c|c|c|c|}
\hline 3. & Blasphemy & Female & $\begin{array}{l}\text { Oh } \\
\text { Tuhanku, } \\
\text { Allah! }\end{array}$ & $\begin{array}{l}\text { Oh God, } \\
\text { Allah! }\end{array}$ & 1 & $1 \%$ \\
\hline 4. & Obscenity & Female & Rojan! & $\begin{array}{l}\text { Humans } \\
\text { do not know } \\
\text { themselves }\end{array}$ & 1 & $1 \%$ \\
\hline 5. & Vulgarity & Male & Heang! & $\begin{array}{l}\text { Female } \\
\text { Genitals }\end{array}$ & 1 & $1 \%$ \\
\hline 6. & Epithets & Male & $\begin{array}{l}\text { Sial! } \\
\text { Bursik }\end{array}$ & $\begin{array}{l}\text { Damn! } \\
\text { Damn! }\end{array}$ & 1 & $3 \%$ \\
\hline 7. & $\begin{array}{l}\text { Insult and } \\
\text { Slur }\end{array}$ & Male & $\begin{array}{l}\text { Pinahan! } \\
\text { Bodat! } \\
\text { Binatang! } \\
\text { Babami! }\end{array}$ & $\begin{array}{l}\text { Pig! } \\
\text { Monkey! } \\
\text { Animal! } \\
\text { Big } \\
\text { mouth! }\end{array}$ & 2 & $7 \%$ \\
\hline 8. & Scatology & Male & Tekku ho! & shit! & 5 & $5 \%$ \\
\hline Tota & Taboo & & & & & $20 \%$ \\
\hline
\end{tabular}

\section{DISCUSSIONS}

After analyzing the data, there were 3 research findings found based on the table. They were presented as follows :

a) Insult and Slur is the most dominant type of taboo language in the context from the conversation of Batak sellers and Batak customers in the bargaining process. Insult is verbal attacks on other people. These words are spoken to harm other people by the word alone. Slurs may be racial, use the psychological qualities of the target. Some insults use animal imagery such as bodat (monkey), pinahan (pig), binatang (animal) and babami (big mouth) in Batak Toba language. Sellers and customers felt that this language is the comfortable language to be said when they felt bored or angry with some of the other people.

b) The second taboo language beside the Insult and slur is Scatology. Scatology refers to human waste products or processes. Scatological is common among children such as Tekku (Shit) in Batak Toba language, Batak people are also comfortable with this language because most Batak people feel that language comes out spontaneously when they felt upset, emotion and anger towards others especially Batak sellers. Sometimes, they felt annoyed when customers bid at very low prices, so they say Tekku (Shit) as a taboo word but with spontaneously without 
thinking the impacts from the word.

c) On the other hand, Cursing, Profanity, Blasphemy, Obscenity, Vulgarity, Insult and slur are some types in appropriate that used in conversations because the languages are so bad language in public so there is just some Batak sellers that used the languages especially in Bataktoba language

In beside it,the dominated people who used taboo language are male because men are easier to get emotional, so they are easier to pronounce taboo language than female. The background of sellers said taboo language were they just said that kind of taboo language when they already felt so hated and disgusted towards customers, and sometimes they would speak the taboo language when they have a close relationship with the other people, so when they say the taboo language, they would not hate each other. But in beside it, sometimes taboo language also would give the impacts for customers.

\section{The Impacts of Taboo Language Towards Customers}

(Teresita, 2014)states that Taboo Language is a borrowed word from Tongan, An Austronesian language means prohibition because the language is considered dangerous when it is spoken for individual or society, it means that if the language is spoken carelessly, it will have an impact. (Katz, 2000)statesthat the impacts of using taboo language is it will make someone feel more aggressive and anger.

The second question about the impacts of taboo language and the reasons that taboo language can give the impacts towards customers at traditional market. Some of theimpacts such as; some of Batak sellers become the aggressive people, becausethey become someone who is hated by others, and they can cause pain to others because they become the people who have the irrational thinking, but sometimes it will not happen when they say the taboo words to their close friends because they already have a very close relationship each other, so the pronunciation of taboo language is only considered as an ordinary word or even a joke such as "bodat (monkey)", in bataktoba language, if someone say "bodat (monkey)" for people who have a close relationship with them, they will think that "bodat (monkey)" is just a joke word and they also will think that it is an ordinary word although "bodat (monkey)" belongs to Insult and Slur taboo word.

On the other hand, from all the impacts the researcher also found that from the all conversations Batak sellers is the dominant people who used taboo language in bargaining process because they become the aggressive people when they did not receive the bargaining process well from costumers.

\section{Bataknese Society Perceptions Towards Their Taboo Language}

From the third question about the Bataknese society perceptions towards their taboo 
language, the researcher found some perceptions from 5 conversations with Batak sellers at Pajak sore Padang Bulan Medan. From the research, there are some Batak people still know about taboo language.

Then, when the researcher asked the sellers about their perception about taboo language in their native language, almost 80 \% Batak people in Pajak Sore Padang Bulan Medan felt dislike about their taboo language, because they thought that it is a bad language, the language can make someone hated and shunned by others if the language is spoken in public. Sellers and customers also could not receive the language because they still think that the language can have a bad impact on children because children would replicate and pronounce the taboo language. The taboo language should also be abolished because it can make a person feel heartache and resentment when listening to the language.

From sellers and customers there are some assumption that taboo language are mostly uttered by lower class people with lower educational background, and association because of people with good educational background in some occasions, they still use indecent and offensive language in their conversation but that is not always true because sometimes there is the association influence. In general, a person's language is influenced by surroundings, because if they were friends with people who say nice language so they would not say the taboo words. The last, Bataknese people generally believed that when people utter taboo language whether they are educated or uneducated, there must be a reason behind it all.

\section{CONCLUSIONS}

Based on the data analysis that presented in the previous chapter, the researcher concludes that taboo language can still be found in the traditional market,taboo language also were mostly uttered by lower class people with lower educational background because people with good educational background in some occasions still use indecent and offensive language in their conversation. Then, the dominated people who used taboo language are malebecause men are easier to get emotional, so they are easier to pronounce taboo language than female and from the all conversations sellers are the dominant people who used taboo language in bargaining process because they become the aggressive people when they did not receive the bargaining process well from costumers but sometimes they would speak the taboo language when they have a close relationship with the other people, so when they say the taboo language, they would not hate each other.

In beside it, there were also impacts of taboo language from some Batak sellers that who often use taboo language towards their customers through several conversations with researcher such as; some of Batak sellers or the other people become the aggressive people, it means that they become someone who is hated by others, and sometimes they can cause pain to others because they become the people who have the irrational thinking. 
Then, someperceptions and knowledge about their taboo language such as almost $80 \%$ Batak people at Pajak Sore Padang Bulan Medan feel dislike about their taboo language, because they thought that the language is a bad language, and it was not the language that can be spoken in public places or anywhere.

\section{REFERENCES}

Cook. (2014). Defenition of Taboo Language. Taboo Language, 10. $\mathrm{Ja}$

y. (1999). Taboo Language in Indonesian Language. English and Literature, 10.

Katz. (2000). The Impacts of Taboo Language . Sociolinguistic Study, 14.

Mahmoud. (2013). A Sociolinguistic View of Linguistic Taboo in Jordanian Arabic. Journal of Multinglingual and Multicultural Development, 16.

Palmer. (2001). Semantic and Pragmatic Theories. Socilinguistic Study, 13.

Teresita. (2014). Taboo Language Meanings. Theory and Practice in Language Study, 11.

Wardhaugh. (2006). Language and Linguistic Study. Sociolinguistic Study, 12.

William. (2012). Qualitative Methods. Research Methodology, 13.

Yoosefi. (2017). The Influence of Gender in Taboo Words. The Effects of Gender on Speaking and Use of Taboos, 16.

Yule. (2010). The Study of Sociolinguistic. Newyork: Cambridge University. 